\title{
АКТУЕЛНИ ПОКУШАЈИ НОРМИРАҢА ГОВОРНЕ ВРСТЕ ЈЕЗИКА У СРПСКОМ И У ДРУГИМ СЛОВЕНСКИМ ЈЕЗИЦИМА
}

\begin{abstract}
У раду се разматра процес утицаја разговорног језика на убрзавање процеса нормирања књижевних језика у словенском простору.
\end{abstract}

Кључне речи: кодификација, норма, споразумевање, конзервативна елита.

Пошто сам на тему нормирања и делимично кодификације „говорне врсте пољског језика" (Лубаш 1986, 85-90)르, као и српског и неких словенских језика говорио више пута, такође и на овом форуму (Лубаш 2004, 5-14; 2007, 17-25), овај рад третирам као допуну и актуализацију ранијих опсервација.

Основне тврдње поменутих публикација тичу се тога: 1) да се разговорна врста језика (не стил, не регистар!) појављује под различитим и неадекватним називима у свим словенским језицима ${ }^{2}$ - и не само у њима - већ и у највећим европским језицима, нпр. немачком ${ }^{3}$, француском ${ }^{4}$ и

1 Пошто пољски термин „оdmiana potoczna” језика не представља синоним за српски „говорни језик” намерно користим нови термин „говорна врста језика”, чиме желим да истакнем системску и комуникацијску ширину те варијанте.

2 Упор. Шкиљан 1988, 51. Подсетимо да се ради о језичкој врсти следећих назива: у српском језику (као и у хрватском) 1) разговорни језик и жаргон , 2) у бугарском језику градски наддиалект /колоквиални език, 3) у руском језику: русская разговорная речь / просторечие / жаргон, 4) у чешком: bе̌žnĕ mluvená čeština /obecná čeština, 5) у пољком: odmiana potoczna / mówiona polszczyzna .

${ }^{3}$ Назван Umgangssprache, уп. А. Шулц (A. Szulc), Odmiany narodowe języka niemieckiego. Geneza- rozwój-perspektywy, Kraków 1999, 26-29.

4 У овом случају се ради о две врсте француског језика : courant (свакодневни) и familie (разговорни). 
енглеском $\left.{ }^{5}, 2\right)$ у последње две деценије се њен удео у јавној комуникацији снажно повећава што доводи до неопходности нормирања те врсте језика, комуникацијске, стилистичке и нормативне условљености, такође и путем кодификације, којој она до тада није била подвргнута уопште или је била вршена само делимично, 3) да и из тих разлога долази до нужности признавања двеју варијантних врста у стандарду словенских језика.

Данас, после петнаестак година које су протекле од времена формулисања горе поменутих теза, оне добијају потврду од стране најважнијих истраживача стратификације појединих словенских језика 6 . Сведоци смо такође повећаног интересовања за разговорну врсту која је описивана са разних позиција: дескрипције корпуса (система), друштвене, као и са позиције језичке политике. Не дешава се, ипак, тако у свим нормативно-кодификационим подухватима и не у свим институцијама, што се уосталом види и на примеру богатог програма Одбора за стандардизацију српског језика, научног, популаризаторског и организационог, у коме недостаје било какав коментар о планираној норми у односу на српски говорни језик (Брборић, Вуксановић, Гачевић (ред.) 2006: 21-24, Вуксановић, Гачевић, Тасић (ред.) 2007: 274-278). Разлике у појединим погледима на суштину разговорности, њен опсег и комуникацијску улогу у принципу се своде на то да се узима у обзир само неједнак број њених карактеристика као посебне стратификацијске категорије, као и број, опсег и функције комуникацијско-друштвено-психичких фактора који представљају услов за њен удео у грађењу текста.

Карактеристике разговорне врсте можемо свести на две паралелне везе дистинктивних особина опозиције у скаларним а не бинарним димензијама:

1. у односу на општу стандардну врсту:

1.1. различит граматички подсистем и у већем обиму лексички систем,

1.2. ограничене функције и номинацијски опсег,

1.3. доминирајуће експресивно-емоционалне функције,

1.4. удео искључиво у директним и примарно вербалним или вербално „стилизованим” и актуализованим говорним чиновима,

5 У енглеском се користе синоними colloquial/informel/everyday language.

6 Уп. нпр. Земска, Катајгородска, Ширјајев 1981; Земска (1973, 1. изд.) 2004; Шведова (1960 1. изд.) 2003; Сиротинина 2003; Химик 2004 у руском језику; Данеш 1997, 160-172; Крчмова, 1997, 160-172; Крчмова, Милерова 2005, 41-75; Крчмова 2006, 102-118 у чешком језику; Виденов 2003; Гладкова, Ликоманова 2002 у бугарском језику; Ристић 2006 у српском језику; Силић 1999, 327; Самарџија 1997; Raslojavanje jezika i književnosti, 2006 у хрватском језику; Качала 1997, 103 у словачком језику. 
1.5. ограничен стилистички обим,

1.6. непотпуно нормирање,

1.7. недостатак кодификације или само делимична кодификација ;

2. у односу на неопшту врсту (неке социолекте, жаргоне, дијалекте и интердијалекте):

- на основу критеријума:

2.1. у односу на опсег:

2.1.1. у НВ (=неопшта врста) - ограничене само на одређене друштвене групе,

2.2. у односу на граматичке и лексичке подсистеме:

2.2.1. у НВ (= неопшта врста ) - делимично другачије у све три врсте,

2.3. у односу на нормирање и кодификације:

2.3.1. у НВ (=неопшта врста ) - не појављује се,

2.4. у односу на разлике у степену вредновања на културно-обичајном плану у узусу: 2.4.1.СВ [=општа-стандардна ] - највише,

2.4.2. ГВ [= општа-говорна] - средње (неутрално),

2.4.3. НВ [= неопшта врста] углавном негативно.

3. Опште врсте - стандардна и говорна имају заједничку карактеристику пун опсег, који обухвата целу комуникацијску заједницу,

4. Неопшта врста (нестандардна и неразговорна) - има ограничен опсег, у одређеним друштвеним и територијалним групама.

Међу врстама сваког од језика постоји стална размена чинилаца система (узајамно позајмљивање чинилаца и друштвено променљива поља номинације и експресије тј. емотивности) која узрокује потешкоће у класификацији чинилаца корпуса, нарочито лексике и пуних текстова. Обраћају на то пажњу истраживачи стандардне и разговорне врсте, као и жаргона у свим словенским језицима (нпр. у српском, узајамно деловање стандардног/разговорног и жаргона - Бугарски 2003: 14-15, 69; у чешком běžně mluvená čeština /obecná čeština - Данеш 1997: 14-18; Крчмова, Милерова 2005: 41-75; у руском - русская разговорная речь / просторечие/ городское просторечие / жаргон - Химик 2003, 15-32 ; Мокијенко и други $2003^{7}$ ). У том контексту скрећемо пажњу на начин изражавања емоција

7 „Объяснений может быть множество, но главное состоит в том, что к началу XXI столетия в русском культурном и языковом пространстве произошла «смена нормативной основы литературного языка»: нормотворческая значимость письменного языка художественной литературы стала уступать свою функцию устной речи публичных каналов общенациональной коммуникации 2. Практически это означает, что постепенно языковое сообщество стало ориентироваться в своем представлении о речевых идеалах и эталонах не на образцовый язык русских писателей, «властителей дум», как это было в XIX 
које карактеришу све врсте, али не и у једнакој мери. На стандардном нивоу емоције се појављују умерено, преко системских творбених средстава, обележених израза као и преко обележавања текста, нарочито на путу случајне метафоризације и метонимизације, док се на разговорном и неопштем нивоу јављају путем често несистемског коришћења творбених средстава, кроз богату и трајну метафоризацију, метонимизацију, као и преко страних лексичких позајмљеница (уп. Лубаш 2003: 249-511; Ожуг 2003: 309-320). Нема, дакле, у том случају великих разлика између опште разговорне врсте и неопштих варијаната, што онемогућује прецизну типологију а олакшава узајамно преплитање у језичкој стварности. Ту се, наиме, појављује синдром сличан „лептиру” који је непокретан јер га је биолог прибио иглом због добијања истраживачких ефеката. Тај непокретни инсект никад не може репрезентовати све особине своје врсте и своје „индивидуалности” у оном облику у ком се појављује у стварности за време лета или тражења хране, када добија променљиве боје и испушта карактеристичне звуке. Исто тако разговорна врста због веће динамике променљивости него што је стандардна, остаје вештачки „непокретна” и описивана само у статичном облику од стране лингвиста. Желећи, ипак, да се приближи стварној слици може се при типовању дистинктивних критеријума послужити скаларношћу особина а не само бинарним супротстављањем појединих врста. Ако узмемо у обзир основне критеријуме нормирања тј. систем, узус, кодификацију и скаларну разлику, добићемо следећу шему опозиције између три врсте језика које нас интересују и привативну особину разговорности:

веке и отчасти в первой половине ХХ столетия, а на звучащую публичную речь средств массовой информации", СМИ"РАЗГОВОРНАЯРЕЧЬ":

Yandex http://www.krugosvet.ru/articles/92/1009206/1009206a1.htm; „ПРОСТОРЕЧИЕ": Aport Google Yandex http://www.krugosvet.ru/articles/66/1006650/1006650a1. htm ; Т. Г. Никитина, Большой словарь русского жаргона, Санкт-Петербург 2000; 
Табела

Норма стандардне и разговорне врсте језика

(на основу : Лубаш 2003, 89 +допуне)

\begin{tabular}{|c|c|c|c|}
\hline \multirow{2}{*}{$\begin{array}{c}\text { Критеријуми } \\
\text { норме }\end{array}$} & \multicolumn{3}{|c|}{ Оорма/Врста } \\
\cline { 2 - 3 } & $\begin{array}{c}\text { Отандардна } \\
\text { (СВ) }\end{array}$ & $\begin{array}{c}\text { Разговорна } \\
\text { (РВ) }\end{array}$ & $\begin{array}{c}\text { Неопшта врста (НВ) } \\
\text { Неки социолекти, } \\
\text { жаргони, територијални } \\
\text { дијалекти и интердијалекти }\end{array}$ \\
\hline 1 & 2 & 3 & 4 \\
\hline $\begin{array}{c}\text { Систем/ } \\
\text { дескрипција }\end{array}$ & + & + & + \\
\hline узус & + & + & + \\
\hline \multirow{2}{*}{ Кодификација } & + & +- & - \\
\hline
\end{tabular}

Скаларност особина

\begin{tabular}{l|l|l|l} 
Висока & Просечна & Ниска & Нема
\end{tabular}

У представљеној шеми узајамних односа између врста на нивоу опште комуникације (државне, националне) највиши културни престиж приписује се стандардној врсти, разговорна врста заузима неутралну позицију а неопште варијанте - најнижу, која је обично негативно оцењивана. У ту валоризацију би требало, ипак, унети следеће допуне: 1) у комуникацијској функцији стандардна врста неутралише свој престиж у малим комуникацијским групама (подгрупама) које користе властите социолекте (нпр. омладински језик, народни дијалекти), 2) у симболичко-идентификационој функцији стандардна врста задржава високи престиж у свим комуникацијским подгрупама, 3) у комуникацијској функцији разговорна врста увек заузима неутрални престиж у директном дискурсу (face-to-face) и делимично у стиловима који користе стратешку персуазију а губи га у другим стиловима на општем нивоу, 4) у свим врстама постоји одређена група изражајних средстава које су стално обележене високим или ниским престижом, нпр. вулгаризми и опсцене речи или тзв. недолична (неадекватна) средства за одређени говорни акт (нпр. стандардна врста, дакле тзв. „pański język/ mówienie po pańsku”/ 
„господски језик, причање господски” у социолекатским срединама или дијалекатска врста, значи тзв. „wsioski język”/,сељачки језик” коришћен у јавној комуникацији). Тако је различита функционална дистрибуција појединих врста повод нарушавања у узусу у којем учествују различите њихове врсте као нпр. у публицистичким и књижевним стиловима. Продубљују је такође „размазане” директиве, у домену културе речи, усред којих преовлађују нормативне системске наредбе над комуникацијским, додатно без узајамних корелација и недовољна едукација, а још у већем степену - све већи јаз између традиције, дубоко укорењене у високој, елитној култури и масовне интернет комуникације која користи права популарне културе и користи се у одређеним врстама јавног дискурса (као што су форуми, блогови, чет) свим облицима језика, а такође и жаргоном, дијалектизмима (ређе) и негативно обележеним социолектима. Таквом стању погодује претпостављање ортографског хаоса и нарушавање свих норми исправности, али пре свега поплава разговорности и жаргона јавног дискурса који се преноси на комуникацију изван мреже. Из коришћених текстова те врсте произилази да овај ортографско-језички конгломерат није истог интензитета у свим језицима. Неки сервери уводе баријере служећи се културно-обичајним модераторима и елиминишући нежељене садржаје и форме. И тако нпр. српски сервер serbian cafe chat даје следеће услове учествовања на чету:

„Правила понашања: Ми смо против: вређања, провоцирања, изношења личних података о другим особама, flood-a [поток речи, светла итд.], рекламирања у свим облицима. Ми смо за: лепо дружење, размену идеја, слободу мишљења". Такође и у серверима других земаља имамо сличне, па чак и рестриктивније услове учествовања у дискурсу мреже, али бивају они врло често заобиђени. На тај начин највише мултидијалекталне, мултисоциолектне, мултилингвалне идиолектске иновације, као и мултикултурне и једноставно неспретне форме изјава продиру у јавни дискурс изван мреже, добијају престиж и представљају узор млађем и слабије образованом делу „интернаута” и поред супротстављања елите. И тако се појавио још један неисцрпан извор разговорног језика али такође и истовремено нове, супстандардне секундарне писане врсте језика. Наиме, интернет варијанта која је приближена системски разговорној врсти, мада није идентична ни у граматичком, ни у лексичком погледу, једноставно је хаотична у односу на комуникацијске моделе других медија. То је врста која се тек рађа и легитимише се почецима својеврсне узусне норме. Погледи на тип интернет језика изражавани у малобројним радовима у принципу се слажу да је комуникација у мрежи не само другачији медиј, већ и одређен комуникацијски „комплекс”, који барем 
у неким одређеним специфичним врстама за тај комплекс користи такође и други језик у односу на остале медије (Гжења 2001; Кита 2003; Јенджејко 2005). На питање чиме би требало да се тај „комплекс” као посебна комуникацијска категорија разликује у језичком погледу, имамо такође мало одговора. На пример: да се карактерише примопредајном интерактивношћу учесника дискурса, потенцијалном шематичношћу, дакле коришћењем тзв. готових модела који су спремни за умножавање, сталном динамиком и променљивошћу садржаја, па чак и доста слободном ортографијом. Ови облици се стално допуњују, граматичком и лексичком разговорношћу која излази из нормализованих сфера, хипертекстуалношћу. Интернет комуникација је једини медиј који гарантује широку примопредајну интерактивност и уједно омогућује у стварном времену коришћење у том истом говорном акту у неким врстама (нпр. у Скајпу) четири кода: писани, говорни, пластични (иконични) и музички, што доводи до ситуационих и скраћених језичких исказа. Истовремено је најбогатији медиј који преноси све могуће врсте; стилове и језичке врсте, у великој мери такође и историјске. Станислав Гајда (Гајда 2000: 19-27) назива ту појаву „медијалним котлом врсте” и „медијалним котлом дискурса”. Тај конгломерат врста, стилова и језичких врста ствара специфичну језичку „мешавину” (стил/врсте) коју можемо назвати или интернет врстом или интернет варијантом разговорне врсте. Карактеристичне језичке особине те врсте/варијанте је приближавају разговорној врсти чија је најважнија особина која се истиче - преображавање високо апстрактног језичког система у процесу директне и природне комуникације у нижи степен ситуационе, актуалне и конкретне апстракције што погодује: 1) редунданцији елемената система, која са семантичке тачке гледишта повећава фонд емотивних експонената а у малом степену утиче на богаћење номинативних средстава, 2) јавном опсегу тих средстава који прелази регионалне и комуникацијске границе, као и границе средине и изазива сакупљање хетеронимичних (спољашњих варијација) чија се дистрибуција налази у надлежности јединке или уских, неконтролисаних од стране више културе друштвених група, 3) томе да при неодређености и због непрецизних принципа репатриције варијаната може фактички доћи и долази до хаотичног узуса тих средстава, 4) ова непрецизност дистрибуције доводи до синонимије граматичких категорија нпр. нестајање флексије доводи до различитих синтаксичких функција исте лексеме у истом морфолошком облику, ту дакле наступа брисање формалних детерминанти граматичко-семантичких категорија, а као последица наступа смањење јасноће значења, 5) привилеговање „лаких” и „економичних” начина деривације нових значења која се заснивају на: 
а) претераној метонимизацији постојећег речничког фонда, б) истицању предности деривације која се заснива на „сечењу” творбених основа, в) формалној и значењској полифункционалности форманата, што доводи до редундантне полисемије, која се значењски распознаје тек и само на текстуалном и комуникацијском нивоу, г) демонстративном нарушавању ортографских и језичких норми у одређеним врстама текста секундарно писаних (Лубаш 2003: 145-158, Јенджејко 2005: 53-135). Све те особине разговорности у максималној скали и у минималном степену уређивања налазе потврду у „дискурсним” текстовима у мрежи. Чини се да даљи развој комуникације типа interface - to interface у још већем степену може олабавити природни и кодификовани систем у стандардној норми и довести до високо либералне нове „норме” у интернет „говорним” врстама (Нововјејски 2001: 65-73), што ће на крају узроковати одвајање интернет норме, а „интернаути” траже то већ сада. Уосталом, већ данас се налазимо пред дилемом: да ли увести у интернет рестрикцијску језичку норму која узима у обзир у већем степену систем и тим самим погодује искључењу из комуникације у мрежи већине друштва или тежити санкционисању формалног (пошто ће културни ићи теже) већ постојећег узуса? У прилог нормативном санкционисању интернет језичке врсте говоре следеће комуникацијске појаве: 1) вишестрана (вишекултурна, вишекодовска и вишедимензионална) језичка комуникација на интернету која се наслања на различите дискурсе и приближава се у многим погледима природним комуникацијским актима али не може да се мери са њима у детаљима кад се ради о „чулном” смислу (ситуационост је перципирана уз помоћ чула), у односу на шта језик остаје у интернету начелни код, 2) језички систем у интернету не подлеже дезинтеграцији а тим пре ни деструкцији, мада наступају његова ограничења и упрошћавања у одређеним врстама интернет исказа који имитирају говорни језик, 3) та упрошћавања су преношена доста произвољно у ортографију која се такође попуњава новим знаковима, 4) новост интернет комуникације се заснива на: а) интегрисању истовремено многих семиотичких знакова у истим говорним чиновима, б) неограниченом и отвореном приступу произвољног броја пошиљалаца и прималаца обдарених огромном количином лингвистичке компетенције, в) на творби хипертекстова, г) ликвидацији временских и просторних комуникацијских баријера, д) на могућности овековечења текстова и сакупљања незамисливог корпуса текстова са светским опсегом, 5) интернет није само „медиј” у комуникационом систему, већ и „комуникацијски комплекс” савременог информатичког друштва који обухвата цео свет (Домбровска 2000, Гођиц 2000; Јенджејко 2005: 246-277). 
Ипак, процес „нормирања” интернет језичке врсте ће бити необично тежак и кодификатори претпостављају да ће бити можда и немогућ. Најозбиљније препреке су : 1) интернационални опсег те комуникације, 2) неопходност промене културног престижа стандардних врста, тј. подизање разговорне врсте језика на ниво високе културе а тим самим снижавање престижа стандарда, 3) у словенским земљама, где стандардне врсте врше симболичке функције - означавају национални и државни идентитет - може доћи до нарочито снажног отпора против депресијације те улоге националних језика (Пипер 2003, 9-163), 4) конзервативизам елита одговорних за култивацију језичке норме. Без обзира на темпо увођења било каквог уређења језичке интернет комуникације, већ само присуство разговорне врсте у том медију утицаће на убрзавање процеса који је нормирају, а који се уосталом делимично већ уводе и у словенском свету.

\section{ЛИТЕРАТУРА}

Брборић, Вуксановић, Гачевић (ред.) 2006: Б. Брборић, Ј. Вуксановић, Р. Гачевић, Српски језик у нормативном огледалу, Београд.

Бугарски 2003: R. Bugarski, Žargon. Lingvistička studija, Београд.

Виденов 2003: М. Виденов, Българската езикова политика, София.

Вуксановић, Гачевић, Тасић (ред.) 2007: Ј. Вуксановић, Р. Гачевић, М. Тасић, Списи Одбора за стандардизацију српског језика. IX, Београд.

Гајда 2000: S. Gajda, Media - stylowy tygiel wspótczesnej polszczyzny. [w:] J. Bralczyk i K. Mosiołek-Kłosińska (red.), Język w mediach masowych, Warszawa, 19-27.

Гладкова, Ликоманова 2002: Г. Гладкова, И. Ликоманова, Языковая ситуаиия: истоки и перспективы (болгарско-чешкие паралели), Praha 2002.

Годзиц 2000: W. Godzic, Język w internecie : czy piszemy to, co myślimy ? (w:) J. Bralczyk, K. Mosiołek-Kłosińska (red.) 2000, Jezyk w mediach masowych, Warszawa, 176-185.

Гжења 2001: J. Grzenia, Internet jako miejsce dialogu [w:] http://dialog.us.edu.pl Данеш 1997: F. Daneš, Situace a celkový stav dnešní češtiny (w:) F. Daneš (red.), Český jazyk na přelomu tisíciletí, Praha, 11-24.

Домбровска 2000: M. Dąbrowska, Język e-maila jako hybryda mowy i pisma (w:) G. Szpila (red.) Język a komunikacja 1. Zbiór referatów z konferencji Język trzeciego tysiąclecia Kraków 2-4 marca 2000, Kraków, 95-111. 
Земска, Китајгородска, Ширјајев 1981: Е. А. Земская, М. В. Китайгородская., Е. Н. Ширяев, Русская разговорная речь. Общие вопросы. Словообразование. Синтаксис, Москва.

Земска 2004: Е. А. Земская, Русская разговорная речь. Лингвистический анализ и проблемы обучения. Наука, „Флинта”, Москва.

Ивић, Клајн, Пешикан, Брборић 1991: П. Ивић, И. Клајн, М. Пешикан, Б. Брборић, Језички приручник, Београд.

Јенджејко 2005: Е. Jędrzejko, Składnia, style, teksty. Wydawnictwo Gnome, Katowice. Качала 1997: J. Kačala, Nová jazyková situácia v Slovenskej republike (w:) S. Ondrejovič (ed.), Slovenčina na konci 20. storočia, jej normy a perspektívy. Sociolingvistika Slovaca 3, Bratislava, 101-107.

Кита, Гжења 2003: M. Kita, J. Grzenia (red.), Porozmawiajmy o rozmowie. Lingwistyczne aspekty dialogu, Katowice.

Крчмова 1997: M. Krčmová, Současná běžná mluva v českých zemích (w:) F. Daneš (red.), Český jazyk na přelomu tisíciletí, Praha, 160-172.

Крчмова, Милерова 2005: M. Krčmová, M. O. Müllerová, Sytuacja współczesnego języka czeskiego (w:) M. Balowski (red.), Rozwój języka czeskiego po aksamitnej rewolucji, Racibórz , 41-75.

Крчмова 2006: М. Крчмова, Процес конституирования современной повседневной речи (в:) Нещименко Г. П. (ред.), Глобализация - етнизация. Етнокултурные процесы, Книга II, Москва, 102-118.

Лубаш 1986: W. Lubaś, Istota potoczności, Biuletyn PTJ XL, 85-90.

Лубаш 2004: В. Лубаш, Две врсте стандарда у словенским језицима, Научни састанак слависта у Вукове дане, 33/1, Београд, 5-14.

Лубаш 2007: В. Лубаш, Дескрипција узуса разговорне врсте језика у нормативним речницима, Научни састанак слависта у Вукове дане, 36/1, Београд, 17-25.

Лубаш 2008: В. Лубаш, Замршени проблеми у нормирању лексике на тлу савремене језичке политике у словенским земљама, Научни састанак слависта у Вукове дане, 37/1, Београд, 29-34.

Нешчименко 2003: Г. П. Нещименко, Языковая ситуация в славянских странах. Опыт описания. Анализ концепций, Москва.

Нововјејски 2001: B. Nowowiejski, Łacina Internetu. (w:) S. Krzemień-Olak, B. Nowowiejski (red.), Przyszłość języka, Białystok, 65-73.

Ожуг 2003: K. Ożóg, Wspólczesna polszczyzna potoczna i jej zmiany w ostatnim dziesięcioleciu (w:) S. Gajda, A. Vidivič Muha (red.), Wspólczesna polska i słoweńska sytuacja językowa. Podobni jezikovni položaj na Poljskem In v Sloveniji, Opole, 309-320. 
Пипер 2003: П. Пипер, Сриски између великих и малих језика, Београд.

Радовановић 2003: М. Радовановић, Sociolingvistika. Treće izdanje, Сремски Карловци - Нови Сад.

Ристић 2004: С. Ристић, Експресивна тексика у српском језику, Београд.

Ристић 2006: С. Ристић, Раслојеност лексике српског језика и лексичка норма, Београд.

Самарџија 1997: M. Samardžija, Utjecaj sociopolitičkih mijena na leksik hrvatskoga jezika u XX. stoljeću, Croatica, 45-46.

Силић 1999: J. Silić, Norme i normiranje hrvatskoga standardnoga jezika (u:) Josip Silić, Rasprave, Zagreb, 326-328.

Сиротинина 1974: О. Б. Сиротинина, Современая разговорная речь и ее особенности, Москва.

Сиротинина 2003: О. Б. Сиротинина, Лексика разговорной речи в системе функииональных стилей современного русского литературного языка. Москва, 2 изд.

Скубиц 2003: A. Skubic, Standardni jezik in sociolekti v slovenski zgodovini in danes (w:) S. Gajda, A. Vidivič Muha (red.), Współczesna polska i słoweńska sytuacja językowa. Sodobni jezikovni položaj na Poljskem in v Sloveniji, Opole, 59-86.

Химик 2004: В. В. Химик, Большой словарь русской разговорной экспрессивной речи, Норинт, Санкт-Петербург.

Шведова 2003: Н. Ю. Шведова, Очерки по синтаксису русской разговорной речи, Москва.

Шипка 1999: Д. Шипка, Опсцене речи у српском језику, Београд.

Шкиљан 1988: D. Škiljan, Jezična politika, Zagreb.

Шулц 1999: A. Szulc, Odmiany narodowe języka niemieckiego. Geneza-rozwójperspektywy, Kraków, 26-29. 


\section{АКТУАЛЬНЫЕ ПОПЫТКИ НОРМИРОВАНИЯ РЕЧИ В СЕРБСКОМ И В ДРУГИХ СЛАВЯНСКИХ ЯЗЫКАХ}

Резюме

Процесс кодификации речевой нормы славянских языков обусловлен объективными потребностями расширенного публичного дискурса в период общественного переустройства, в котором участвуют собеседники, находящиеся на различных интеллектуальном и культурном уровнях. Этот речевой „вид” (по-разному именуемый в стратификационных типологиях языка) включает уже имеющуюся среднюю позитивную престижную позицию и становится средством естественного взаимопонимания на общем уровне национальной и государственной общности в нескольких важных областях - в персвазийной журналистике, политической пропаганде, рекламе и художественной литературе. В последнее время речевой „вид” также стал средством дискурса в сети глобального масштаба. Таким образом, возникает необходимость „нормирования” языка интернета. Однако процесс „нормирования” интернетного варианта языка будет чрезвычайно труден или даже, как предполагают кодификаторы, невозможен. Наиболее важными препятствиями являются следующие: 1) интернациональный масштаб данной коммуникации; 2) необходимость изменения культурного престижа стандартных видов, т.е. повышение уровня разговорного языка до уровня высокой культуры, и тем самым - снижение престижа литературного языка; 3) в славянских странах, где литературные языки выполняют символические функции, выражая национальную индивидуальность и государственность, может начаться сильное сопротивление утрате литературными языками этой роли; 4) консерватизм элиты, отвечающей за культивирование языковой нормы.

Несмотря на темпы введения любого урегулирования языковой коммуникации в интернете, уже само присутствие разговорной речи в этой среде будет воздействовать на ускорение процессов, которые нормируют данный язык и которые частично уже вводятся и в славянском мире. 